\title{
Effects of Levamisole on the Immune Responses of Experimentally Malnourished Rats
}

\author{
S. O. OLUSI, ${ }^{(23)}$ W. J. E. JESSOP, AND A. SHOROYE \\ Department, of Chemical Pathology, Haematology and Immunology, Faculty of Health Sciences, University of Ife, \\ Ile-Ife, Nigeria
}

\section{Summary}

Levamisole (Ketrax), an anthelmintic drug commonly used in the tropics, has been found to restore the impaired spontaneous rosette-forming lymphocytes and delayed cutaneous hypersensitivity reactions in experimentally malnourished rats. It, however, has no effects on plaque-forming cells.

The drug was also found to reconstitute the histologic integrity of the thymus in malnutrition.

\section{Speculation}

Due to the diminished immune response in malnutrition, mortality usually occurs as a result of superimposed infections like diarrhea and bronchopneumonia. It is speculated that levamisole that potentiates cellular immunity in malnutrition may aid the recovery of children with kwashiorkor and marasmus, particularly those with gastroenteritis and bronchopneumonia.

By a conservative estimate, at least 400 million people, most of them from Africa and Asia, are suffering from malnutrition today. Ten million of these, mostly children under the age of five yr, die annually. Death in these children is usually due to secondary infection associated with the diminished immune responses that have been reported by several authors $(2,4,6,8,9,11)$. At a Workshop on the Immunology of malnutrition held during the Third International Congress of Immunology in Sydney, Australia in July 1977, it was generally believed that the information derived from the immunology of malnutrition should be channelled towards the management of children with protein-energy malnutrition. In response to this, the authors decided to investigate the effects of levamisole (Ketrax), a known immuno-stimulatory agent on the immune response of experimentally malnourished rats.

\section{MATERIALS AND METHODS}

\section{ANIMALS}

Male white albino rats (Rattus rattus norvegicus) were used for this study. They were bred in the Animal House of the Faculty of Health Sciences, University of Ife.

Levamisole (trade name, Ketrax) was obtained from the Pharmacy Department of the University of Ife Teaching Hospitals Complex. The preparation used was in syrup. Five $\mathrm{ml}$ of the syrup contains $40 \mathrm{mg}$ levamisole as hydrochloride. Ketrax is manufactured by Imperial Chemicals Industry, Pharmaceuticals Division, Macclesfield, Cheshire, England.

Sheep blood was obtained from the Agricultural farm of the University of Ife. After centrifugation, sheep red blood cells were washed in sterile Hank's balanced salt solution and stored in the solution containing $2 \%$ fetal bovine serum and penicillin at $4{ }^{\circ} \mathrm{C}$. Mouse cube diet and Average Grade baker's flour were used in the present study. Their compositions have been given in a previous publication (11). Achitina fulica hemocyanin was obtained from the Giant African Snail as described in a previous publication (12).

\section{DOSE OF LEVAMISOLE}

From reports in the literature, most investigators working on the immunostimulatory effects of levamisole in experimental animals have usually employed $5 \mathrm{mg} / \mathrm{kg}$ body wt. In view of the impaired immunologic responses in malnutrition, it was decided to use levamisole in doses of $10 \mathrm{mg} / \mathrm{kg}$ body wt.

\section{ADMINISTRATION OF LEVAMISOLE}

Levamisole was given orally to the rats by means of a gastric tube. The animal was held in an upright position while the polythene tubing was gently passed into the stomach, the animal exhibiting a characteristic gagging when the tube was in the stomach. The required dose of levamisole was then gently injected through a syringe attached to the tubing.

\section{EXPERIMENTAL DESIGN}

Male white albino rats were malnourished by feeding them on flour diet for two months. The malnourished animals were than randomized into four groups, each group consisting of 12 animals. The animals in group $A$ (the controls) continued to be fed on the flour diet. The animals in group B were refed on the standard laboratory mouse cube diet.

The animals in group $\mathrm{C}$ were fed on the flour diet but, in addition, they received $10 \mathrm{mg} / \mathrm{kg}$ body wt levamisole on alternate days for 30 days so that each animal received 15 doses of the drug during this period. The animals in group $D$ were refed on the high protein mouse cube diet but, in addition, they had levamisole on alternate days for 30 days.

After this period of 30 days, the primary humoral immune response was assessed using six animals from each group of rats by estimating the number of plaque-forming cells in the spleen five days after intraperitoneal immunization with sheep red blood cells using the method described in a previous publication (11).

Table 1. Effects of levamisole on the number of plaque-forming cells (PFC) during the primary and secondary immune responses to sheep red blood cells in malnourished rats

\begin{tabular}{lccc}
\hline Rat group & $\begin{array}{c}\text { No. of an- } \\
\text { imals }\end{array}$ & $\begin{array}{c}\text { Average no. of PFC/ } \\
\text { spleen during the pri- } \\
\text { mary responses }{ }^{a}\end{array}$ & $\begin{array}{c}\text { Average no. of PFC/ } \\
\text { ondary response }{ }^{b}\end{array}$ \\
\hline $\begin{array}{l}\text { Malnourished, } \\
\text { control } \\
\text { Malnourished, } \\
\text { treated with } \\
\text { levamisole }\end{array}$ & 6 & 3800 & 4100 \\
\hline${ }^{a} P>0.05$. & 4000 & 4200 \\
${ }^{b} P>0.05$.
\end{tabular}


Table 2. Effects of levamisole on body and organ wt, histology of thymus, number of spontaneous rosette-forming lymphocytes, and delayed cutaneous hypersensitivity reactions in malnourished rats

\begin{tabular}{|c|c|c|c|c|c|c|c|c|c|}
\hline Rat group & $\begin{array}{l}\text { No. in } \\
\text { group }\end{array}$ & $\begin{array}{c}\text { Mean } \\
\text { body wt. s } \\
\text { (g) }\end{array}$ & $\begin{array}{l}\text { Mean } ~ \\
\text { spleen wt. } \\
\text { (g) }\end{array}$ & $\begin{array}{l}\text { Mean thy- } \\
\text { mus wt. } \\
\text { (g) }\end{array}$ & $\begin{array}{l}\text { Mean thymic } \\
\text { cortical thickness } \\
(\mu)\end{array}$ & $\begin{array}{l}\text { Average no. of } \\
\text { Hassal's corpus- } \\
\text { cle/high field }\end{array}$ & $\begin{array}{l}\text { Average diame- } \\
\text { ter of Hassal's } \\
\text { corpuscle }(\mu)\end{array}$ & $\begin{array}{c}\text { Average percent } \\
\text { of spontaneous } \\
\text { PFC }(\%) \\
\end{array}$ & $\begin{array}{c}\text { Average area of } \\
\text { skin induration } \\
\left(\mathrm{mm}^{2}\right)\end{array}$ \\
\hline Malnourished control & 6 & 30.0 & 0.2 & $0.04^{a}$ & $15.0^{a}$ & $0^{a}$ & $a$ & $10^{a}$ & $36^{a}$ \\
\hline $\begin{array}{l}\text { Malnourished rats } \\
\text { treated with levami- } \\
\text { sole alone }\end{array}$ & 6 & 33.2 & 0.25 & $0.10^{a}$ & $26.0^{a}$ & $3.0^{a}$ & $1.0^{a}$ & $26^{a}$ & $100^{\alpha}$ \\
\hline $\begin{array}{l}\text { Malnourished rats } \\
\text { refed on high-pro- } \\
\text { tein diet alone for } 15 \\
\text { days }\end{array}$ & 6 & 47.5 & 0.4 & 0.16 & $35.0^{b}$ & $5.0^{b}$ & $2.5^{b}$ & $45^{b}$ & $172^{b}$ \\
\hline $\begin{array}{l}\text { Malnourished rats } \\
\text { refed on high-pro- } \\
\text { tein diet on treat- } \\
\text { ment with levami- } \\
\text { sole }\end{array}$ & 6 & 49.3 & 0.45 & 0.21 & $45.0^{b}$ & $10^{b}$ & $5.0^{h}$ & $62^{b}$ & $256^{b}$ \\
\hline
\end{tabular}

Cell-mediated immunity was assessed by estimating the number of spontaneous rosette-forming cells in the peripheral blood of the animals using the method described by Higgins and Stack (5). Delayed type hypersensitivity skin reactions to hemocyamin were assessed using the remaining six animals from each group.

The method used for skin testing has been described in a previous publication (10).

Histologic sections of the spleen and thymus (where present) from a representative of each group of rats were made and thymic cortical thickness and diameter of the Hassall's corpuscles were estimated using the micrometer eyepiece. Thymic cell counts were also made by dispersing a piece of the thymus in Hank's balanced salt solution and counting the number of cells on a hemocytometer chamber.

Statistical analyses of results were carried out according to the methods described by Lutz (7).

\section{RESULTS}

The results obtained are presented in Tables 1 and 2; Table 1 shows that levamisole, at the dose employed in this study had no significant effect $(P>0.05)$ on the number of plaque-forming cells to sheep erythrocytes either in normal or malnourished rats. From Table 2, it could be deduced that malnutrition causes atrophy of the thymus gland and a significant reduction in the number of spontaneous rosette-forming lymphocytes in the peripheral circulation. When malnourished rats were treated with levamisole alone for 30 days a significant increase $(P<0.05)$ occurred in thymic weight, cell count, and cortical thickness. In addition, the drug caused a significant increase in the number of spontaneous rosette-forming lymphocytes and improvement in delayed type hypersensitivity skin reaction to hemocynin. Table 2 also shows that the effects on the histology of the thymus and cell mediated immunity of refeeding the malnourished rats with a high protein diet were superior to those obtained when levamisole alone was used. However, a combination of levamisole and refeeding on high protein diet produced significantly more marked improvements in cell-mediated immune responses than refeeding on a high protein diet alone.

\section{DISCUSSION}

The results of this study showed that treatment of malnourished rats with levamisole resulted in marked improvement in cellular immunity but that such improvement was inferior to that produced by refeeding on a high protein diet. Combination of levamisole with a high protein diet on the other hand produced more marked improvement on cellular immunity than refeeding on a high protein diet alene.
There is no doubt that the best treatment for malnutrition is an improved diet. But it is known that in certain cases of kwashiorkor, treatment with a high protein diet often results in overwhelming infections due to the severely diminished cellular immunity. It is in these cases that treatment with levamisole may prove useful.

Levamisole is a synthetic compound and is the $\mathrm{L}$-isomer of racemic tetramisole. It is a simple chemical compound-2,3,5,6tetrahydro-6-phenyl-imidazo $(2,1-b)$ thiazole. It is a nematocidal drug that causes the death of the nematodes by producing muscular paralysis associated with inhibition of an enzyme called fumarase reductase. Because its discovery and subsequent uses in the treatment of worm infestations in man, certain reports have indicated that it may have some immunostimulatory effects. Among the earliest reports of its immunostimulatory property were its restoration of antibacterial immunity (14) and increase graft versus host reaction in $\mathrm{F}$ hybrid recipients after inoculation of spleen cells from a parental donor previously stimulated by injection of levamisole (13). Reports have also shown that it restored cutaneous delayed hypersensitivity reaction in elderly subjects (20) and in anergic patients with cancer (17). It has been used in the treatment of recurrent aphtheous stomatitis and herpes infections (16) and in the prevention of upper respiratory tract infection in children (18). This study shows that it improved cellular immunity in malnourished animals and may, therefore, be useful in the treatment of severe cases of malnutrition.

Our findings that levamisole influences cell-mediated and not humoral immunity agree with previous reports $(3,19,21,22)$. In spite of the extensive literature on the immunostimulatory effects of levamisole, its mode of action is not known (15). The facts that levamisole, in this study, caused increases in thymic weight, cell count, cortical thickness, and the number of Hassall's corpuscles would tend to suggest that levamisole stimulates the thymus gland. Such stimulation might lead to the production of thymic hormones that, in turn, stimulate cell-mediated immune reactions. Further studies are being continued by us on a clinical trial involving the use of levamisole in the treatment of children with kwashiorkor.

\section{REFERENCES AND NOTES}

I. Brugmans, J., Schuermans, V., and De Cock, W.: Restoration of host defense mechanisms in man by levamisole. Life Sci., 13: 1499 (1973).

2. Geefhuysen, J., Rusen, E. U., Katz, J., Ipp, T., and Metz, J.: Impaired cellular immunity in Kwashiorkor with improvement after therapy. Brit. Med. J., 4: 527 (1971).

3. Hadden, J. W., Coffey, R. G., Hadden, E. M., Lopez-Corrales, E., and Sunshine, G. H.: Effects of levamisole and imidazole on lymphocyte proliferation and cyllic nucleotide levels. Cell Immunol., 20: 98 (1975).

4. Harland, P. S., and Brown, R. E.: Tuberculin sensitivity following B.C.G. vaccination in undernourished children. E. African. Med. J., 42: 233 (1965).

5. Higgins, D. A., and Stack, M. J.: Bovine lymphocytes recognition of cells forming spontaneous (E) rosettes. Clin. Exptl. Immunol., 27: 348 (1977). 
6. Jayalakshmi, V. T., and Gopalan, C.: Nutrition and Tuberculosis. Part 1. An Epidemiological study. Ind. J. Med. Res., 46: 87 (1958).

7. Lutz, W.: Statistical methods as applied to immunological data: In: Handbook of Experimental Immunology. Vol. 3, 2nd Ed. (Blackwell,)

8. McFarlane, H., and Hamid. J.: Cell-mediated immune response in malnutrition. Clin. Exptl. Immunol., 13: 153 (1973).

9. McFarlane, H., Olusi, S. O., Adeshina, H. A., Ade-Serrano, M. A., and Oshunkoya, B. O.: Evidence of impaired immunological response in malnourished human population. XIII Symp. Swed. Nutr. Found., 23 (1976).

10. Olusi, S. O., and Elegbe, R. A.: Immunogenicities of haemocyanins from the giant African snail (Achatina fulica) and the keyhold limpett (Megathura crenulata). Comp. Biochem. Physiol., Part B 56: 289 (1977).

11. Olusi, S. O., and McFarlane, H.: Effects of early protein-calorie malnutrition on the immune response. Pediatr. Res.. 10: 707 (1976).

12. Olusi, S. O., Wallwork, J. C., Elegbe, R. A., and McFarlane, H.: the giant African snail (Acathin fulica) Hemocyanin, Immunochemistry, 13: 425 (1976).

13. Renoux, G. and Renoux, M. Action immunostimulante de derives du phenylimidothiazole sur les cellules spleniques formatrices danticorps $\mathrm{C}$. R. Acad. Sci. (D) (Paris) 274: 756 (1972).

14. Renoux, G., and Renoux, M.: Antigenic competition and non-specific immunity after a rickettsial infection in mice: restoration of antibacterial immunity of phenyl imidazole treatment. J. Immunol., 109: 761 (1972).

15. Rosenthal, M., Trahert, U., and Muller, W.: The effect of levamisole on peripheral blood lymphocyte in patients with rheumatoid arthritis and ankylosing spon-

Copyright (c) 1979 International Pediatric Rese arch Foundation, Inc. $0031-3998 / 79 / 1311-1237 \$ 02.00 / 0$ dylitis. Clin. Exptl. Immunol., 25: 493 (1976).

16. Symoens, J., and Brugmans, J.: Levamisole treatment of recurrent aphthous stomatitis and herpes. Brit. Med. J., 4: 592 (1974)

17. Tripodi, D., Parks, L. C.. and Brugmans, J.: Drug induced restoration of cutaneous delayed hypersensitivity in anergic patients with cancer. N. Engl. J. Med., 298: 354 (1973).

18. Van Cinkel, R. F., Effects of levamisole on spontaneous rosette-forming cells in murine spleen. Eur. J. Immunol., 6: 305 (1975).

19. Van Eygen, M., Znamensky, P. Y., Heck, E., and Raymaekers, I.: Levamisole in prevention of recurrent upper respiratory tract infections in children. Lancet. l: 382 (1976).

20. Verhargen, H., Cree, J. D., and Verbruggen, P.: Immune responses in elderly cuti-negative subjects and the effect of levamisole. Verh. Disch. Ges. Inn. Med., 79: 623 (1973).

21. Woods, W. A., Fligelman, M. J., and Chrisgos, M. A.: Effects of levamisole on the in vitro immune response of spleen lymphocytes. Proc. Soc. Exp. Biol. Med., 148: 1048 (1975).

22. Whybran, J., and Govnerts, A.: Levamisole and human lymphocyte surface markers. Clin. Exptl. Immunol., 27: 319 (1977).

23. Requests for reprints should be addressed to: S. O. Olusi, M. D., Department of Chemical Pathology, Hematology and Immunology, Faculty of Health Sciences, University of Ife, Ile-Ife, Nigeria.

24. Received for publication August 8, 1978.

25. Accepted for publication December 6, 1978 